Irina Subotić

Univerzitet u Novom Sadu

Akademija umetnosti

Departman likovnih umetnosti

Srbija
UDC 73/76.072.2:929 Pašut K.(047.53)

050.488ZENIT

doi 10.5937/ZbAkU2109020S

Intervju

\title{
Stogodišnjica časopisa Zenit (1921-1926-2021) kroz razgovor sa profesorkom emeritom Kristinom Pašut
}

Zbornik radova Akademije umetnosti doprinosi obeležavanju stogodišnjice objavljivanja prvog broja jugoslovenskog časopisa Zenit (1921-1926) studijama posvećenim dosada nedovoljno istraživanim temama iz oblasti naših istorijskih avangardi, a okupljeni krug saradnika iz nekoliko zemalja svedoči o živom interesovanju stručnjaka i danas za probleme kojima se Zenit bavio, pre svega za njegov neiscrpan izvor kreativne energije i humanističke vere da kultura i umetnost mogu da preobraze svet. Razgovor s Kristinom Pašut (Krisztina Passuth), uvaženom istoričarkom moderne umetnosti, profesorkom emeritom i nekadašnjom kustoskinjom, obavljen u proleće 2021, u vreme pandemije Covida19 odvijao se - razume se elektronskom poštom na relaciji Beograd-Budimpešta-Beograd. Tema je obeležavanje stogodišnjice časopisa Zenit $i$ zenitizma, i odnosi se na veze, sličnosti i razlike između mađarske i jugoslovenske avangarde. Razlog što smo se upravo prof. Pašut obratili s molbom za intervju, specijalno za Zbornik, zasniva se na činjenici da je ona stekla izuzetan ugled svojim istraživanjima mađarskih, ali i transnacionalnih veza među avangardnim ličnostima, pojavama i pokretima dvadesetih godina prošlog veka. Prof. Pašut je u stručnim krugovima veoma cenjena i zbog svojih značajnih rezultata u muzejskom radu, najpre u Mađarskoj nacionalnoj galeriji i Muzeju lepih umetnosti u Budimpešti, a potom u Nacionalnom muzeju moderne umetnosti pri Centru „Žorž Pompidu“ i u Muzeju moderne umetnosti grada Pariza. Započela je sa objavljivanjem u Mađarskoj, a od sredine sedamdesetih godina prošlog veka, kada je živela u Parizu, sarađivala je sa najprestižnijim izdavačkim kućama poput Flamariona (Flammarion) i drugih. Organizovala je niz istorijskih izložbi velikana modernizma i avangarde, poput Františeka Kupke i Lasla Moholi-Nađa (Moholy-Nagy László) a zahvaljujući fundamentalnoj knjizi u izdanju Flamariona Les Avant-Gardes de l'Europe Centrale, 1907-1927 (Avangarde u Centralnoj Evropi, 1907-1927), u kojoj je veliku pažnju posvetila jugoslovenskom zenitizmu, Kristina Pašut je postala svetski priznati stručnjak 
za komparativne studije istorijskih avangardi. Nakon tzv. „plišane revolucije”, vratila se u Mađarsku 1992. godine i započela profesorsku karijeru na Odeljenju za istoriju umetnosti jednog od najstarijih univerziteta u regionu, koji nosi ime Loránda Eötvösa (ELTE). Tu je stekla titulu profesorke emerite a dobitnica je i više značajnih nagrada za naučni rad: Lajoš Nemet, Sečenji, Moholi-Nađ̛ i dr.

- Kao istoričarka umetnosti stekli ste ogroman ugled u svetu svojim studijama i knjigama posvećenim prvoj polovini 20. veka, posebno nakon što se vaša izuzetno značajna studija o avangardama u Flamarionovom izdanju pojavila sredinom osamdesetih godina. Među prvima pišete o umetnosti $i$ kulturi Srednje Evrope, čije je osnovne premise postavio Česlav Miloš, a što je u to vreme postao prihvatljiv pojam imajući u vidu evropska, ali i svetska previranja pred pad Berlinskog zida, tačnije pred kolaps Sovjetskog Saveza. Kako piše Aleksander Fjut (Fiut), naziv Srednja Evropa je imao ne samo politički $i$ pragmatičan, već i kulturni smisao. Označavao je potrebu da se napravi distinkcija između Istočne i Zapadne Evrope, da se ustanove posebnosti koje obeležavaju tako velike kulture, kao što su mađarska, poljska, tadašnja čehoslovačka i jugoslovenska, ali i brojni pojedinci i ustanove koje su dale velike doprinose Evropi i celom svetu.

U kom trenutku ste počeli da istražujete avangarde, posebno zenitizam?

Dobro se sećam: prvi put sam za pokret zenitizam i njegove ciljeve saznala 1970. godine, kada sam došla do kompletnog faksimila mađarskog časopisa $M A$ (1916-1925). Pročitala sam ga od korica do korica i veoma pažljivo pregledala sve ilustracije. U to doba u našoj zemlji se teško dolazilo do drugih, uistinu pravih, originalnih izvora avangarde. Istini za volju, tada se ni međunarodna izdanja nisu previše bavila pojavama van granica Zapadne Evrope. Ni jezička barijera - mađarski nije od pomoći za razumevanje slovenskih jezika - nije delovala ohrabrujuće. Sa velikim interesovanjem sam u junskom broju časopisa MA iz 1921.' (štampanom u Beču) pročitala - i to na mađarskom - prikaz Boška Tokina o zenitizmu. Članak pod naslovom „Zenit, zenitizam” izveštavao je o ciljevima tada još do kraja nedefinisanog novog jugoslovenskog pokreta. ${ }^{2}$ Živo, neagresivno, u pozitivnom i multinacionalnom tonu, Tokin je tumačio ono što mu je prethodilo. Objašnjavao je da je ishodište zenitizma - ekspresionizam, da ga je dotakao, a onda stigao do apstraktnog metakosmičkog ekspresionizma, do najviše umetničke forme čija je teritorija mikrokosmos, sa čovekom u središtu... U tom smislu Zenit ne poznaje granice i aktivno, u dobroj veri, pruža ruku

1 MA, VI god., br. 7, 1921, str.100.

2 Prvi broj Zenita je objavljen 1.februara 1921.godine u Zagrebu (prim. I. S.). 
svima njemu srodnima. Autor piše da je pokretač Zenita Ljubomir Micić3 , a pominje i ostale saradnike, kao što su Virgil Poljanski ${ }^{4}$ i strani stvaraoci - Francuzi Ivan Gol (Goll), Andre Salmon (André Salmon), Maks Žakob (Max Jacob), Mađar Mihalj Eden (Ödön Mihályi), Italijan Enriko Prampolini (Enrico Prampolini), Austrijanac Egon Šile (Egon Schiele) i drugi. Naglašava da Zenit nije samo jedna od karika nove kulture, već i propagator novog svetskog fenomena. Iako Boško Tokin nije dugo bio među Zenitovim najužim saradnicima, već je glavna figura ostao Ljubomir Micić, na početku je bio veoma prisutan i aktivan, pokušavajući da oko Zenita okupi što širi međunarodni krug, posebno saradnika iz Pariza. U tome je njegov poseban značaj.

Narednih godina nastojala sam, shodno tada raspoloživim mogućnostima, da se u okviru svojih istraživanja evropske avangarde upoznam bliže sa Zenitovim odnosom prema likovnim umetnostima, i uopšte - sa idejama časopisa kroz objavljene članke, studije, ilustracije, radove njegovih saradnika i drugo, i da to uključim u svoje studije.

Za to mi se pružila izuzetna prilika tek 1983. u Beogradu, na monumentalnoj izložbi u Narodnom muzeju pod nazivom Zenit $i$ avangarda dvadesetih godina sa pratećim katalogom, bogatim programom posvećenim avangardi i sa međunarodnom konferencijom na kojoj sam učestvovala. Bilo je to pravo otkrovenje, pre svega jer sam tada neposredno upoznala književnu i likovnu umetnost vezanu za časopis Zenit, ali i autorke izložbe, vas, Irina, i Vidu Golubović, kao i brojne druge istraživače avangarde. Imala sam priliku i da se suočim sa raznovrsnošću, kontradikcijama i problemima ovog avangardnog pokreta.

Istovremeno, vi ste mi omogućili da dođem do mnogih informacija, do neobjavljenih tekstova i studija kao rezultata vaših proučavanja, i tako sam bila upućena u značaj i osobenosti zenitizma. Mislim da je pomenuta izložba Zenit $i$ avangarda dvadesetih godina bila prva, veoma značajna istočno- i srednjeevropska manifestacija posvećena avangardi koja je na tako kompleksan način predstavila ovaj važan pokret. Sledile su je mnoge izložbe posvećene avangradama dvadesetih godina u drugim srednjeevropskim sredinama, ono što su kulture Zapadne Evrope učinile deceniju ili dve ranije, tokom šezdesetih i sedamdesetih godina, za razne avangardne pokrete i časopise $\mathrm{u}$ različitim kulturnim ambijentima.

- U kojoj meri je časopis Zenit i njegov program, po Vašem mišljenju, sličan, a po čemu se razlikuje od ostalih avangardnih pojava dvadesetih godina prošlog veka? Šta ih sve obeležava u tom ranom postratnom periodu?

\footnotetext{
3 Rođen u Sošicama, nekada srez Jastrebarski, sada Žumberački 1895, umro u Beogradu 1971. (prim. I. S.).

4 To je jedan od pseudonima Branka Ve Poljanskog (1897- 1947), kojim je evocirao Majske Poljane u kojima je rođena njegova majka Marija. Majske Poljane su u naše dane poznate pre svega po katastrofalnom zemljotresu koji je nedavno gotovo uništio ovo naselje u Baniji (prim. I. S.).
} 
Na pitanje koliko se Zenit razlikuje od drugih avangardnih časopisa, u principu i na prvi pogled, lako je odgovoriti: naime, kada je bio pokrenut u zimu 1921. godine, jedva se razlikovao od ostalih medija sličnog profila. Tek je kasnije, tokom daljih razvoja ideja i shodno društvenoj atmosferi i političkim situacijama, on menjao svoj ton i ciljeve, i tako se udaljavao od drugih, njemu bliskih glasila. Povezivalo ih je to što su svi nastali u društvenoj atmosferi nakon okončanja Prvog svetskog rata koji je zahvatio sve evropske države, i otuda ih povezuju srodne istorije i sudbine, koje karakterišu i njihove koncepcijske principe. Tako su ih povezivali zajednička prošlost i slična aktuelnost društvene, ekonomske pa i kulturne situacije početkom dvadesetih godina: svi su bili opterećeni osiromašenjem u ratu, prisustvom smrti i pandemijskih bolesti, ali i postratnim političkim i društvenim prilikama, pretrpljenim poniženjima i nadom u bolju budućnost. Talasi netrpeljivosti prema starom svetu i spremnost da se menja svet smenjuju se na stranama gotovo svih avangardnih publikacija, iz čega se rađaju (ili nestaju) konfrontacije, trvenja, sukobi i protivrečnosti.

$\mathrm{U}$ to vreme mnoge evropske države nisu samo na mapi promenile mesto, i mada nisu uvek uspele da se u potpunosti državnički ostvare, one su zahvaljujući različitim, drugačijim i snažnim intelektualnim i modernim strujanjima u nauci i kulturi, novim shvatanjima i aktuelnim idejama, uspele da se duhovno preporode. Sigurno je da se Zenit i njemu srodni časopisi i pokreti u širem regionu, kao što su mađarski $M A$, češki Pasmo, Devětsil, Disk, RED, poljski Blok i Zwrotnica, rumunski Contimporanul, Integral ili Punct ili ruski časopis Bещь-Objet-Gegenstand, koji su u Berlinu izdavali Ilja Erenburg (Илья Григорьевич Эренбург) i Lazar El Lisicki (Эль Лисицкий) - ne mogu procenjivati samo po njihovoj estetici. U njima se ogledaju istorija njihove zemlje i snaga novog posleratnog stanja. Monarhije - Nemačka, Austrougarska i Ruska raspale su se, a njihove krhotine su počele da žive samostalne živote, shodno ulozi koju im je odredila volja vladajućih moćnika posle sklapanja mira.

Završen je rat, stare uloge su se promenile, raniji neprijatelji su se, ponekad, pronašli kao saradnici - ukoliko se nisu gledali preko nišana. Postepeno su se rađale i suprotnosti - od Rusije je nastao Sovjetski Savez, za neke uzor koji treba slediti, a komunizam su jedni smatrali jedinim putem kojim treba krenuti, a drugi u njemu videli novog neprijatelja. Sve to nije bilo moguće raščistiti na samom početku dvadesetih godina, već nešto kasnije, i to postepeno i po cenu brojnih suprotnosti, pa i tenzija.

Jugoslavija je ujedinila narode raznih jezika, vera, istorija i shvatanja i koliko god se to u početku činilo srećnim rešenjem, kasnije je pokrenulo mnoga pitanja i izazvalo brojne sukobe kako u svakodnevnom životu, tako i u kulturi.

- Bilo bi zanimljivo da uporedite predstavnike najveće mađarske i jugoslovenske avangarde, Lajoša Kašaka (Lajos Kassák) i Ljubomira Micića, koji su intenzivno sarađivali, ali nije poznato da su se sreli. 
Časopis Zenit, na čelu sa Ljubomirom Micićem, piscem, pesnikom, filozofom po obrazovanju, urednikom i kolekcionarom, pojavio se u pravo vreme za uspešno uspostavljanje međunarodnih kontakata - u opštoj, izrazito antiratnoj atmosferi, posebno među mladim intelektualcima koji su proživeli užase Prvog svetskog rata. Osnovan 1921. godine u Zagrebu (a od 1923. do 1926. izlazio je u Beogradu), Zenit je bio prethodnik ili savremenik velikog broja srednjeevropskih časopisa i istovremeno je sarađivao sa istomišljenicima širom sveta. Suočavao se s mnogim teškoćama, čemu su doprinosile ne samo lokalna, konzervativna atmosfera, već i nezavidna finansijska situacija, ali su ga ugrožavali i suprotstavljeni stavovi i rasprave među predstavnicima odnosno samim saradnicima Zenita.

Oba časopisa, i mađarski aktivisitčki $M A$, koji je najpre izlazio u Budimpešti, a potom, posle zabrane, u Beču, i jugoslovenski Zenit jasno su ispoljavali antiratne stavove i levu orijentaciju, i u tom smislu su se njihovi principi poklapali, ali su se u drugim pogledima razmimoilazili. Ipak zajedničke karakteristike i Zenita i $M A$ odnosile su se na otvoreni, internacionalni duh, na želju za stvaranjem nove kulture i uspostavljanjem širokih međunarodnih veza. To se pre svega odnosilo na intenzivnu saradnju Zenita sa Parizom, ali i sa Berlinom, tačnije sa međunarodnim krugom stvaralaca oko Hervarta

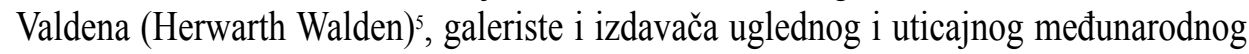
časopisa Der Sturm, što je bilo blisko i mađarskim avangardistima. Saradnja je najpre vođena prepiskom i razmenom tekstova, poezije, reprodukcija i reklama, a onda i časopisa. Dok glavni mađarski aktivista Lajoš Kašak nije mogao zbog političkih i ekonomskih prilika lako da uspostavi lični kontakt, Ljubomir Micić i njegova supruga Anuška Nina-Naj, a nešto kasnije i mlađi Micićev brat Branko Ve Poljanski, posetili su u krajem leta 1922. godine Berlin. Za tu priliku su objavili poseban nemački broj Zenita i pisali o svojim tamošnjim brojnim susretima. Sa svoje strane, Kašak je u časopisu MA veoma uspešno predstavljao mnoge nezavisne umetničke pravce, i to ne samo lokalne, već i one iz Holandije, Nemačke, Rusije...

Rekla bih da je časopis $M A$ bio sistematičniji i čvršće se držao svoje logike i principa, tako da je doprineo da najtalentovaniji stvaraoci krenu novim putem kojim su se udaljili od tradicionalnog, figurativnog izražavanja i približili konstruktivnom, tačnije konstruktivističkom shvatanju stvaralaštva u čemu je arhitektura igrala važnu ulogu. S druge strane, široki krug saradnika Zenita je bio eklektičan, tako da nije ostvaren jedinstven zajednički stil. Oba časopisa su izuzetno cenila i smatrala merodavnom tada već razvijenu rusko-sovjetsku novu umetnosti - Vladimira Tatlina (Владимир Евграфович Татлин), Lazara El Lisickog, Kazimira Maljeviča (Казимир Северинович Малевич), Aleksandra Rodčenka (Александр Михайлович Родченко) i drugih. Osim ruskih stvaralaca, razume se, u oba glasila su bili prisutni i igrali veliku ulogu i drugi nosioci značajnih avangardnih pravaca i to na različite načine. Tako je, na

5 Pravo ime mu je Georg Lewin (prim. ur.). 
primer, za Kašaka bio posebno privlačan međunarodni dadaizam i Tristan Cara (Tzara), s kojim su se i Kašak i Micić dopisivali, dok su za Micića bili značajniji italijanski futurizam, Filipo Tomazo Marineti (Filippo Tommaso Marinetti) i brojni drugi futuristi zbog njihove vizije modernog i dinamičnog, tehnički i tehnološki naprednog sveta.

Ali, iako su se po svojim nazorima i životnim putevima Micić i Kašak vremenom udaljili, zajednička im je bila dvostruka obdarenost: obojica su bili veoma vezani i za likovno i za literarno stvaranje. Kašakov dvojaki talenat se u najvećoj meri ispoljio između 1921. i 1926. u njegovim slikama-pesmama i manifestima, a Micić je pored svojih brojnih tekstova, rasprava i poema - bio i strasan kolekcionar dela likovne avangarde koju je predstavljao na stranama časopisa Zenit, kao i u mnogim drugim zenitističkim publikacijama. Za javnost je otvorio i Galeriju Zenit u redakcijama svog časopisa najpre u Zagrebu, a potom i u Beogradu. Njegova je zasluga i što je posebnu pažnju obratio na specifičan i promišljeni značaj tipografskih i grafičkih rešenja, zahvaljujući kojima su slova, reči, slogani pa i celi rečenični sklopovi pretvarani u slike i tako postajali vizuelno upečatljiviji nego u običnoj štampi. To je bilo jedno od najefektnijih i najsugestivnijih sredstava komunikacije toga doba, i oba stvaraoca, i Micić i Kašak, dobro su ga iskoristili u svojim izdanjima.

Osim toga, oba časopisa i njihove glavne aktere - Micića i Kašaka - moguće je uporediti analizirajući svaku od njihovih delatnosti: tekstove, korespondenciju, ilustracije, organizaciju izložbi, sistem njihovih ličnih kontakata... I daljim poređenjem ta dva inovativna, po važnosti veoma istaknuta časopisa - MA i Zenit - došlo bi se do brojnih sličnosti ali i različitosti.

- Kako vidite te dihotomije u zenitizmu - saradnike različitih opredeljenja $i$ stavova, ali sve upereno u istom pravcu, u želji da se kulturom i umetnošću utiče na svakodnevni život, na realnost, na menjanje realnosti kojom niko nije bio zadovoljan?

Osnivači i najbliži saradnici časopisa Zenit bili su odista veoma različiti: dok je Ljubomir Micić bio izraziti predstavnik srpske samosvesti, kao Srbin rođen u Hrvatskoj koji nije bio oberučke prihvaćen u zagrebačkoj sredini (a kasnije se desilo isto i u Srbiji!), njegovog brata Banko Ve Poljanskog je privlačio duh Zapada, iako su obojica bili izrazito levičarskog raspoloženja. Boško Tokin je najpre formulisao manifest ekspresionizma, a zatim bio jedan od autora manifesta zenitizma (juna 1921), ali je - kao i Dragan Aleksić, koji je bio vrlo aktivan u ranom zenitizmu, mada se više posvetio dadaizmu - ubrzo napustio saradnju s Micićem. Mnoge niti vezivale su Micića za Ivana Gola (Yvan Goll), čiji je almanah Les Cinq Continents prevodio Krležu i Crnjanskog, ali i Mađare Endrea Adija (Ady) i Lajoša Kašaka. Tako je preko francuskog avangardnog izdanja i Tokina uspostavljena veza sa Ivanom Golom. Tokin je u tom 
društvu, verovatno, bio duhom najmoderniji: prevashodno se bavio filmom, filmskom kritikom i estetikom, a autor je i zanimljivog romana o modernom gradu. ${ }^{6}$

Micić je nešto kasnije formulisao koncept „barbarogenija“ kojim će se „balkanizovati Evropa“. U tekstovima je slavio snagu balkanskog varvarstva, novog čoveka sa Balkana i nikada nije odustao od svojih osnovnih nazora: čak je u Parizu, gde je deset godina živeo u izbeglištvu, napisao roman na francuskom pod nazivom Barbarogénie le Décivilisateur. Smatrao je da su staroj, umornoj i ratom još uvek iscrpljenoj Evropi, potrebne nove ideje, nove snage, novi ljudi, novi stvaraoci koje je on video u Balkanu, nazivajući ga ,šstim kontinentom.“

Poljanski je u Parizu 1925. godine vodio burnu diskusiju s Marinetijem: izjašnjavao se protiv fašizma i prebacivao Marinetiju što se ne protivi fašističkim agresivnim manifestacijama, kao što je bilo paljenje Slovenačkog narodnog doma u Trstu.

Imajući u vidu da u domaćoj sredini nije bio dobro primljen i da nije našao dovoljno širok dijapazon stvaralaca koji bi potkrepljivali ideje koje je zastupao u Zenitu, Miciću su bili preko potrebni oslonci u inostranstvu. Želeo je da poznati umetnici-poput Aleksandra Arhipenka (Александр Порфирьевич Архипенко), Lasla Moholi-Nađa, El Lisickog, Ilje Erenburga, Vasilija Kandinskog (Василий Васильевич Кандинский), Osipa Zadkina (Осип Цадкин) i drugih - priznaju zenitistički pokret, objavljuju u časopisu i učestvuju na Prvoj Zenitovoj međunarodnoj izložbi nove umetnosti, čiju je organizaciju Micić započeo u Zagrebu, a uspeo da priredi u Beogradu aprila 1924. godine. Izložba - prva posvećena avangardnoj umetnosti u ovom delu Evrope predstavila je preko sto dela iz trinaest zemalja u to vreme najprogresivnijih umetnika, ali njen značaj nije bio prepoznat blagovremeno, već tek mnogo decenija kasnije: došla je prerano u Beograd. Najveći broj tih eksponata danas čini zaostavštinu Ljubomira Micića, nakon njegove smrti, i pod krovom je beogradskog Narodnog muzeja.

- Kako vidite sudbinu braće Micić? Vaša knjiga 'Les Avant-Gardes de l'Europe Centrale, 1907-1927’ (iz 1987) je odigrala posebnu, neočekivanu - gotovo detektivsku-ulogu.

Izgnan iz Zagreba, jer se zamerio moćnim ljudima, Ljubomir Micić je u Beogradu nastavio sa radom 1923. godine, ali i sa žustrim polemikama, da bi nakon zbirke svojih pesama objedinjenih u knjizi Antievropa, a zatim i tekstom Zenitizam kroz prizmu marksizma (sa potpisom dr M. Rasimov, što je verovatno njegov pseudonim) bio policijski i sudski progonjen. Pri begu ka Parizu od pomoći mu je bio upravo Marineti. Čini se, bar izdaleka, da je uzrok prividnog neprijateljstva prema Evropi i ideal „barbarogenija“ koji ,spasava“ posustalu Evropu, bio rezultat loše atmosfere koja 6 U pitanju je roman Terazije objavljen 1932. godine (prim. I.S.). 
je Micića okruživala u domovini. Po mom mišljenju, možda nikada ne bi pisao tako agresivno da su u Zagrebu i Beogradu više cenili njegovu važnu delatnost i prepoznali njegov poseban način originalnog mišljenja.

Tako je decembra 1926. završena prava i dinamična, autentična avangardna delatnost časopisa Zenit. U Francuskoj, gde je Micić živeo čitavu deceniju, nastavio je da se druži sa svojim bivšim saborcima, čak je nameravao i da obnovi izdavanje časopisa Zenit, ali došla su druga vremena i više nije bilo takvog poleta kao posle Prvog svetskog rata. Micićeve knjige, tačnije memoarski romani pisani na francuskom, sa ilustracijama njegovog brata Branka Ve Poljanskog, gotovo da nisu imali odjeka. Poljanski je u vidu manifesta - performansa na Terazijama - besplatno podelio svoje knjige i javno napustio literarnu karijeru, posvetivši se slikarstvu. Čak je nekoliko puta i izlagao u uglednim pariskim galerijama gde su učestvovali i umetnici poput Pabla Pikasa (Pablo Picasso), Amedea Modiljanija (Amedeo Modigliani), Marka Šagala (Marc Chagall) i drugih.

Ali gasili su se avangardistički plamenovi koji su hranili generacije mladih stvaralaca posle Prvog svetskog rata. Poljanski je mukotrpno živeo u blizini Pariza, rano umro (1947) tako da njegova deca nisu ni znala ko im je bio otac i čime se bavio. Po svoj prilici njihova majka nije ni sama prepoznavala značaj umetničkog angažovanja svoga muža. Tek s knjigom koju ste pomenuli - Les Avant-Gardes de l'Europe Centrale - krajem osamdesetih godina me je u Parizu pronašao Stefan Poljanski (Stéphane Poliansky), jedan od četvoro Brankove dece, kada je shvatio da se u mojoj knjizi dosta govori o njegovom ocu. Tu je doznao mnoge podatke, a onda je i sam istraživao, nabavljao očeve knjige, kataloge, crteže i slike, i tako sastavljao kockice u mozaičnu sliku života i rada njihovog oca Branka.

Što se tiče Ljubomira Micića - poznato je da je on bio izopšten iz javnog života u socijalističkoj Jugoslaviji - sve do smrti 19v।. godine, optužen za nacionalizam i šovinizam i smatran potpuno bezvrednim autorom. Vi ste, Irina, bili među retkim posetiocima u njegovom beogradskom stanu i na grobu njegove supruge Anuške.

Kao kustos Muzeja savremene umetnosti u Beogradu, povremeno sam sretala Ljubomira Micića između 1967. i 1970. godine. U tim dugim viđenjima četvrtkom posle podne, Micić nije rado evocirao svoju avangardnu prošlost, već je u razgovorima insistirao na problemima koji su njega tada mučili - o istorijskim zabludama, o potrebi da se zaštiti ćirilica, o sudskim sporovima koje je i dalje vodio, o lošim komšijama... Bio je ranjen životnim nedaćama, uplašen progonima, unesrećen odlaskom voljene supruge, tihi čovek prodornog pogleda i sigurnog stava, čovek monologa i nepresahlih ideja... ali usmerenih u nekom drugom, meni neprepoznatljivom pravcu.

Zahvaljujući Vašoj knjizi i preporuci, Kristina, srela sam $i$ ja Stefana Poljanskog, najpre u Parizu, a zatim i u Beogradu. On je žarko želeo da dozna što 
više o svom ocu i da dobije bar neko Brankovo delo, ali - kao što je poznato - nakon Micićeve smrti juna 1971. godine, ostavinska rasprava se čekala deset godina, jer su se uzalud tražili naslednici: deca Branka Poljanskog u to vreme nisu ni znala ko im je bio otac. Sud je konstatovao da Micić nema naslednika, pa je tako njegova cela bogata zaostavština podeljena između Narodnog muzeja i Narodne biblioteke Srbije. Stefan Poljanski, njegov brat i sestra nisu bili spremni da pokrenu novu parnicu, a zakonski nije bilo osnova da se bilo šta izdvoji iz Narodnog muzeja i dodeli onima kojima bi, $u$ nekoj drugoj konstelaciji, ta zaostavština pripadala. I to je još jedan znak zlog usuda koji je pratio braću Micić... Ceo jedan vek, koji sada obeležavamo.

(Prevela s mađarskog Vera Konjović) 